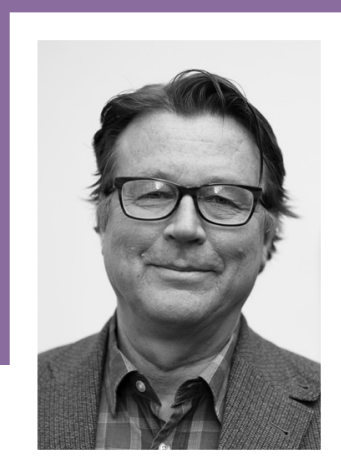

\title{
P̈̈̈̈KIRJOITUS
}

\section{MaAhanMUUTTAJIEN KOULUTUKSESSA PARANNETTAVAA JOKA ASTEELLA}

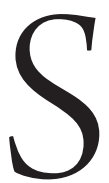

UOMEN PERUSKOULUN nostivat maailmanmaineeseen 2000-luvun alusta lähtien tehdyt PISA-arvioinnit. Muualta tuli runsaasti opetushallinnon väkeä, rehtoreita ja opettajia omin silmin näkemään, miten maailman paras koulujärjestelmä toimii. Vieraat halusivat viedä Suomenmallia kotimaahansa. Järjestelmien ja käytäntöjen kopioiminen maasta toiseen on kuitenkin erittäin ongelmallista, eikä välttämättä onnistu lainkaan.

Hyvien keskimääräisten oppimistulosten lisäksi Suomi erottui keskenään tasalaatuisilla kouluilla ja muita maita pienemmällä heikosti osaavien oppilaiden osuudella. Kansainväliset vertailut osoittivat, että meillä lähes kaikki oppilaat oppivat lukemaan ja laskemaan, vaikka nuoret eivät koulunkäynnistä pitäneetkään.

MAAHANMUUTTAJAT OVAT panneet koulutusjärjestelmän stressitestiin. Tutkimusten mukaan maahanmuuttajaperheet suhtautuvat lastensa koulutukseen suurin odotuksin. Uussuomalaiset arvostavat koulutusta ja uskovat, että siihen sijoitetut ponnistukset parantavat mahdollisuuksia päästä hyvään ammattiin ja arvostettuun asemaan yhteiskunnassa.

Maahanmuuttajaperheiden lapset pitävät koulunkäynnistä kantaväestöön lukeutuvia lapsia enemmän.
PISA-arvioinnit ovat kuitenkin vuodesta toiseen systemaattisesti osoittaneet, että suomalainen peruskoulu on epäonnistunut nostamaan heidän oppimistuloksiaan edes lähelle kantaväestöön lukeutuvien oppilaiden keskimääräistä tasoa.

Ero maahanmuuttajalasten ja kantasuomalaisten oppimistulosten välillä on vertailumaiden suurin, kertoo OECD-järjestön julkaisema Low-Performing Students: Why They Fall Behind and How to Help Them Succeed -raportti (2016). Esimerkiksi vuonna 2015 suomalaislapsista 11 prosenttia osasi matematiikkaa huonosti, kun maahanmuuttajaoppilaiden joukossa vastaava luku oli peräti 45 prosenttia.

Lähes 35 prosenttiyksikön suuruinen ero kantaväestön ja maahanmuuttajien välillä on suurempi kuin missään muussa PISA-tutkimukseen osallistuneessa maassa. OECD-maissa ryhmien välinen ero on alle puolet Suomen erosta. Kantaväestön ja maahanmuuttajalasten ero on samanlainen muissakin testatuissa oppiaineissa. Peruskoulun huonoilla oppimistuloksilla on kohtalokkaat seuraukset nuoren tulevaisuudelle.

HELSINGIN JA TURUN YLIOPISTOJEN yhteisen TRANSIT-tutkimushankkeen tulokset osoittavat, että maahanmuuttajanuorilla on kantaväestöä suurempi 
riski jäädä ilman toisen asteen tutkintoa. He jäävät yhteishaussa ilman koulutuspaikkaa tai keskeyttävät opintonsa esimerkiksi heikon koulumenestyksen ja puutteellisten opiskeluvalmiuksien vuoksi (Yhteiskuntapolitiikka 1/2017).

Tutkijat kuvaavat myönteisten koulutusasenteiden ja runsaiden vaikeuksien yhdistelmää "maahanmuuttajataustaisten nuorten paradoksiksi": erityisesti pojilla on keskimääräistä myönteisempi asenne koulunkäyntiin, vaikka he muita useammin kokevat sen vaikeaksi. Peruskoulu ei osaa muuntaa maahanmuuttajapoikien innostusta ja myönteistä asennoitumista hyviksi oppimistuloksiksi.

Kansallinen koulutuksen arviointikeskus (KARVI) päätyi parin vuoden takaisessa arviossaan niin ikään siihen, että perusopetuksen jälkeinen nivelvaihe on vaikea erityisesti maahanmuuttajataustaisille nuorille, koska kaikkien suomen tai ruotsin kielen taito ei riitä jatko-opiskeluun. Koulutustarjonta on riittämätön etenkin alueilla, joilla on paljon maahanmuuttajataustaisia nuoria.

MAAHANMUUTTAJIEN TYÖLLISTYMINEN ja muu osallisuus kertovat kotoutumisesta. Uussuomalaisten vaikeudet päästä työhön ovat kantaväestöä monin verroin suuremmat. He ovat kertoneet kokevansa suoranaista syrjintää työhönotossa: monien kansallisuuksien kohdalla työttömyys mitataan kymmenissä prosenteissa. Maahanmuuttajille suunnatut työvoimapoliittiset toimet taas ovat osoittautuneet heikoiksi ja riittämättömiksi tai suorastaan vääriksi.
Työ- ja elinkeinoministeriön teettämä tutkimus Maahanmuuttajat ja työvoimapoliittisten toimenpiteiden vaikuttavuus (2017) kertoo, että tutkitusti tehokkaita toimia, kuten työvoimapoliittista ammatillista koulutusta ja palkkatukea, on käytetty maahanmuuttajien työllistämiseen paljon vähemmän kuin kantaväestöön. $\mathrm{Ne}$, jotka ovat osallistuneet vain kotoutumiskoulutukseen, työllistyvät jonkin verran heikommin kuin ne, jotka eivät ole osallistuneet mihinkään toimiin.

Yksin kotoutumiskoulutus ei riitä, vaan se on ymmärrettävä pohjaksi muille, kohdennetuille työvoimapoliittisille toimille. Vasta yhdessä ne voivat johtaa maahanmuuttajien yhä vakaampaan työmarkkinaasemaan. Mutta kotoutumisajanjakson aikana saatu työkokemus on työllistymiselle monin verroin vaikuttavampi tekijä: lyhyidenkin kotoutumiskoulutukseen yhdistettyjen työjaksojen tiedetään edistävän työllistymistä paremmin kuin minkään muiden toimien.

Maahanmuuttajataustaisten koulutukseen kaivataan yhä paremmin tarpeisiin osuvia, vaikuttavia keinoja. On pidettävä huolta oppimisen perustasta. Siksi perusopetus on tärkein. Tuoreimmat kansainväliset arvioinnit paljastavat kaksi uudenlaista muutossuuntaa suomalaisessa koulussa: kotitaustan vaikutus oppimistuloksiin ei enää vähene vaan on alkanut vahvistua, ja koulujen väliset erot ovat kasvaneet. Nykyisen hallituksen koulutukseen tekemät resurssivähennykset eivät ainakaan paranna maahanmuuttajalasten oppimistuloksia eivätkä kavenna kotitaustan mukaisia koulutuseroja.

Heikki Silvennoinen 